\title{
Salinibacterium amurskyense gen. nov., sp. nov., a novel genus of the family Microbacteriaceae from the marine environment
}

\author{
Suk Kyun Han, ${ }^{1}$ Olga I. Nedashkovskaya, ${ }^{2}$ Valery V. Mikhailov, ${ }^{2}$ \\ Seung Bum Kim ${ }^{1}$ and Kyung Sook Bae ${ }^{1}$ \\ ${ }^{1}$ Korean Collection for Type Cultures, Korea Research Institute of Bioscience and \\ Biotechnology, 52 Oun Dong, Yusong, Daejon 305-333, Republic of Korea \\ ${ }^{2}$ Pacific Institute of Bioorganic Chemistry of the Far-Eastern Branch of the Russian Academy \\ of Sciences, Pr. 100 Let Vladivostoku, 159, Vladivostok, 690022, Russia
}

Correspondence Seung Bum Kim sbk01@kribb.re.kr

\begin{abstract}
Three bacterial strains were isolated from sea-water samples taken from Amursky Bay of the Gulf of Peter the Great, East Sea. The isolates, designated KMM 3670, KMM $3673^{\top}$ and KMM 3928 , were Gram-positive, non-motile, aerobic, non-spore-forming, irregular, rod-shaped actinobacteria. They grew well at mesophilic temperatures and neutral $\mathrm{pH}$ and tolerated up to $10 \% \mathrm{NaCl}$, although salt was not essential for growth. The three strains shared all morphological properties and most physiological characteristics tested. Based on subsequent chemotaxonomic and phylogenetic analyses, it was evident that the strains represented a distinctive taxon in the family

Microbacteriaceae. The strains contained a major amount of menaquinone with 11 isoprene units; lysine and ornithine were the major cell-wall diamino acids. In 16S rDNA analysis, the three strains formed an independent phylogenetic lineage within the tree encompassed by members of the family Microbacteriaceae. It is notable that the tested strains form the first described taxon of Microbacteriaceae that inhabits a marine aquatic environment. The three strains evidently merit recognition as a single species of a novel genus in the family Microbacteriaceae, for which the

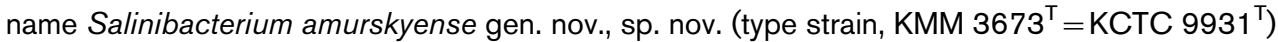
is proposed.
\end{abstract}

The family Microbacteriaceae Park et al. (1993) emend. Rainey et al. 1997 (Stackebrandt et al. 1997) consists of actinobacteria that are irregularly shaped, aerobic, non-motile, non-spore-forming and Gram-positive and have $\mathrm{G}+\mathrm{C}$-rich genomic DNA. Fifteen genera with validly published names currently comprise the family Microbacteriaceae (Table 1), which includes various saprophytic members as well as some pathogenic members of agricultural importance (Yamada \& Komagata, 1972; Davis et al., 1984; Zgurskaya et al., 1992, 1993; Groth et al., 1996; Takeuchi et al., 1996; Suzuki et al., 1997; Takeuchi \& Hatano, 1998; Kämpfer et al., 2000; Männistö et al., 2000; Evtushenko et al., 2000, 2001, 2002; Tsukamoto et al., 2001; Behrendt et al., 2002).

Published online ahead of print on 20 June 2003 as DOI 10.1099/ ijs.0.02627-0.

Abbreviations: DAB, diaminobutyric acid; KCTC, Korean Collection for Type Cultures, Daejon, Republic of Korea; KMM, Collection of Marine Microorganisms, Vladivostok, Russia.

The GenBank/EMBL/DDBJ accession numbers for the 16S rDNA sequences of strains KMM $3673^{\top}$, KMM 3670 and KMM 3928 are AF539697, AF539698 and AF539699, respectively.
Cell walls of microbacteria are characterized by the presence of diamino acids such as lysine, ornithine and diaminobutyric acid (DAB), the distribution of which is one of the key chemotaxonomic markers for generic differentiation (Schleifer \& Kandler, 1972). Menaquinones with 9-12 isoprene units (MK-9-12) are the predominant isoprenoid quinones and straight or branched, saturated fatty acids constitute the major membrane lipid components (Jones \& Collins, 1989; Collins \& Bradbury, 1992). The cell-wall peptidoglycan is type B sensu Schleifer \& Kandler (1972); no mycolic acid is found.

Members of the family Microbacteriaceae are widespread throughout natural and artificial habitats, such as plants, soil, dairy products, sewage, mushrooms, insects and groundwater. Some members, e.g. species of the genera Microbacterium and Subtercola, have been isolated from freshwater samples (Dias \& Bhat, 1962; Dias et al., 1962; Männistö et al., 2000). However, there has not yet been any report of the isolation of microbacteria from the marine environment.

During the study of bacterial diversity in a marine bay area, actinobacteria were isolated from sea-water samples by 
using a conventional selective isolation technique and were subjected to further taxonomic investigation. The bacterial isolates shared a number of morphological and physiological properties and exhibited characteristic features that were consistent with their classification in the family Microbacteriaceae. From the results of a polyphasic taxonomic study, it is evident that the bacterial isolates merit recognition as a novel taxon within the family Microbacteriaceae, for which the name Salinibacterium amurskyense gen. nov., sp. nov. is proposed.

Sea-water samples were collected in June 2000 from Amursky Bay of the Gulf of Peter the Great, East Sea, at a depth of $5 \mathrm{~m}$ (salinity, $33 \%$; temperature, $15^{\circ} \mathrm{C}$ ) and strains KMM 3670 ( = KCTC 9930), KMM 3673 ${ }^{\mathrm{T}}\left(=\right.$ KCTC 9931 $\left.{ }^{\mathrm{T}}\right)$ and KMM 3928 (=KCTC 9932) were isolated on marine agar 2216 (Difco). After primary isolation and purification, the strains were cultivated at $28^{\circ} \mathrm{C}$ on marine agar 2216 (Difco) and stored at $-80^{\circ} \mathrm{C}$ in marine broth (Difco) supplemented with $20 \%(\mathrm{v} / \mathrm{v})$ glycerol.

To determine the oxidative-fermentative metabolism of glucose, bacterial strains were inoculated into modified oxidation-fermentation medium (Hugh \& Leifson, 1953; Smibert \& Kreig, 1994). Oxidase activity was determined by the tetramethyl p-phenylenediamine method (Tarrand \& Gröschel, 1982). Catalase activity was tested by addition of $3 \%(\mathrm{v} / \mathrm{v}) \mathrm{H}_{2} \mathrm{O}_{2}$ solution to bacterial colonies to check for the appearance of bubbles. Hydrolysis of casein, cellulose, DNA, gelatin and urea, production of acetoin and indole (Voges-Proskauer reaction), nitrate reduction and hydrogen sulfide production were tested according to the methods described by Smibert \& Kreig (1994). Degradation of polysaccharides and growth at different $\mathrm{NaCl}$ concentrations were tested by using medium that consisted of $5 \mathrm{~g}$ peptone, $2 \mathrm{~g}$ yeast extract, $1 \mathrm{~g}$ glucose, $0.02 \mathrm{~g} \mathrm{~K}_{2} \mathrm{HPO}_{4}$ and $15 \mathrm{~g}$ agar in 11 water $(1: 1$ natural sea water and distilled water) at $\mathrm{pH} 7 \cdot 5-7 \cdot 8$. For the determination of optimal $\mathrm{pH}$ for growth, medium that consisted of $5 \mathrm{~g}$ peptone, $2 \mathrm{~g}$ yeast extract, $1 \mathrm{~g}$ glucose, $0.02 \mathrm{~g} \mathrm{KH}_{2} \mathrm{PO}_{4}$ and $0.05 \mathrm{~g}$ $\mathrm{MgSO}_{4} \cdot 7 \mathrm{H}_{2} \mathrm{O}$ in $1 \mathrm{l}$ water $(1: 1$ natural sea water and distilled water) was used and the $\mathrm{pH}$ of the medium was adjusted with $1 \mathrm{M}$ solutions of $\mathrm{K}_{3} \mathrm{PO}_{4}$ and $\mathrm{HCl}$. Hydrolysis of chitin $(1 \%, \mathrm{w} / \mathrm{v})$ and alginate (sodium salt, $0 \cdot 1 \%)$ was determined by examining clear zones that developed around colonies. Arginine dihydrolase activity was determined by using the method of Thornley (1960), modified by Lelliott et al. (1966). Production of acid from carbohydrates and alcohols was tested on oxidation-fermentation medium for marine bacteria (Leifson, 1963). Susceptibility to antibiotics was examined by the conventional diffusion plate method. Discs were impregnated with the following antibiotics (amounts per disc): ampicillin $(10 \mu \mathrm{g})$, benzylpenicillin $(10 \mu \mathrm{g})$, carbenicillin $(100 \mu \mathrm{g})$, gentamicin $(10 \mu \mathrm{g})$, kanamycin $(30 \mu \mathrm{g})$, lincomycin $(15 \mu \mathrm{g})$, neomycin $(30 \mu \mathrm{g})$, oleandomycin $(15 \mu \mathrm{g})$, polymyxin B (300 U), streptomycin $(10 \mu \mathrm{g})$ and tetracycline $(30 \mu \mathrm{g})$. All tests were carried out at $28^{\circ} \mathrm{C}$. The $\mathrm{G}+\mathrm{C}$ content of genomic DNA was determined 
by the thermal denaturation method (Marmur \& Doty, 1962), in which an Escherichia coli strain ( $G+C$ content, $50 \mathrm{~mol} \%$ ) served as a reference. DNA extraction, PCR and sequencing of $16 \mathrm{~S}$ rDNA followed previously described procedures (Kim et al., 1998). The obtained sequence data were aligned with those of representative members of selected genera that belong to the family Microbacteriaceae by using PHYDIT version 3.1 (Chun, 2001). Phylogenetic trees were inferred by using suitable programs of the PHYLIP package (Felsenstein, 1993). Phylogenetic distances were calculated from the model of Jukes \& Cantor (1969) and trees were constructed following the FitchMargoliash (Fitch \& Margoliash, 1967), maximum-likelihood (Felsenstein, 1981) and neighbour-joining (Saitou \& Nei, 1987) algorithms. Bootstrap analysis was performed with 1000 resampled datasets by using the SEQBOOT and CONSENSE programs of PHYLIP. Preparation of cell walls and TLC determination of cell-wall diamino acids followed procedures described by Bousfield et al. (1985); HPLC for the quantitative analysis of amino acids was performed by the service at the Korea Basic Science Institute (Daejon, Republic of Korea). Peptidoglycan acyl type was determined according to the procedure of Uchida \& Seino (1997). Menaquinones and phospholipids were analysed by using standard procedures (Minnikin et al., 1984). To determine fatty acid methyl esters, the strains were cultivated on marine agar (Difco) at $25^{\circ} \mathrm{C}$ for $24-48 \mathrm{~h}$. Extraction and analysis of cellular fatty acids were performed according to the procedures for the SHERLOCK Microbial Identification system (MIDI).

Isolates KMM 3670, KMM $3673^{\mathrm{T}}$ and KMM 3928 grew well on marine agar plates. All strains were Gram-positive, nonmotile, aerobic, non-spore-forming, irregular, rod-shaped cells. Growth occurred between 4 and $37^{\circ} \mathrm{C}$ (optimal temperature, $25-28^{\circ} \mathrm{C}$ ) and between $\mathrm{pH} 4.5$ and 11.0 (optimal $\mathrm{pH}$ range, $7 \cdot 2-7 \cdot 5$ ). The strains tolerated up to $10 \% \mathrm{NaCl}$ with an optimal concentration of approximately $1-3 \%$, although salt was not required for growth. All three strains were arginine dihydrolase-, oxidase- and ureasenegative, catalase-positive and did not reduce nitrate or produce hydrogen sulfide. Indole and acetoin were not produced (Voges-Proskauer reaction). Growth did not occur on MacConkey agar.

Cell-wall hydrolysates of the strains contained major amounts of lysine and ornithine as diagnostic cell-wall diamino acids; the molar ratios of alanine : glycine : glutamic acid:lysine: ornithine were estimated to be $1 \cdot 0: 1 \cdot 0: 0 \cdot 4$ : $0 \cdot 25: 1 \cdot 0$. Cell extracts contained MK-11 as the major isoprenoid quinone and also a smaller amount of MK-10. Phosphatidylglycerol and diphosphatidylglycerol were the major characteristic phospholipids. The membrane fatty acids of strain KMM $3673^{\mathrm{T}}$ consisted of 12-methyl tetradecanoic acid (anteiso- $\mathrm{C}_{15: 0} ; 40.4 \%$ ), 14-methyl pentadecanoic acid (iso- $\mathrm{C}_{16: 0} ; 34 \cdot 7 \%$ ), 12-methyl tridecanoic acid (iso- $\mathrm{C}_{14: 0} ; 14 \cdot 7 \%$ ), 13-methyl tetradecanoic acid (iso- $\mathrm{C}_{15: 0} ; 6.6 \%$ ) and 14-methyl hexadecanoic acid (anteiso- $\mathrm{C}_{17: 0} ; 2 \cdot 8 \%$ ). The DNA G $+\mathrm{C}$ content of KMM $3673^{\mathrm{T}}$ was $61 \cdot 0 \mathrm{~mol} \%$. Chemotaxonomic profiles of the tested strains, together with their morphological properties, were consistent with their classification in the family Microbacteriaceae (Jones \& Collins, 1989; Collins \& Bradbury, 1992).

Comparison of chemotaxonomic properties, including cellwall diamino acids, isoprenoid quinones, acyl type, fatty acid profiles and DNA G $+C$ content, is a key criterion for the differentiation of genera in the family Microbacteriaceae (Table 1; Tsukamoto et al., 2001; Evtushenko et al., 2002). However, generic separation based on chemotaxonomic profiles is not always straightforward; for example, the genera Leifsonia and Leucobacter cannot be distinguished by using these chemical criteria (Takeuchi et al., 1996; Evtushenko et al., 2000). 16S rDNA sequence analysis gives a more clear-cut view of their relationship, as the two genera form distinctive clades in phylogenetic trees (Evtushenko et al., 2000; Fig. 1). It is therefore clear that combined comparison of chemotaxonomic properties and $16 \mathrm{~S}$ rDNA sequences enables the separation of each member of the family Microbacteriaceae.

Strains KMM 3670, KMM $3673^{\mathrm{T}}$ and KMM 3928 shared identical 16S rDNA sequences and formed a distinctive phylogenetic lineage in 16S rDNA analysis of 1397 nucleotide positions, with Leucobacter komagatae as the nearest neighbour (Fig. 1). However, the branch that consisted of the tested strains and L. komagatae was neither supported strongly by bootstrap analysis nor recovered in trees constructed by using other algorithms (Fig. 1). In contrast, the tested strains were related to the clade that includes Agreia and Subtercola in Fitch-Margoliash and maximum-likelihood trees (data not shown). In the comparison of sequence similarity, the tested strains were related more closely to Subtercola boreus DSM $13056^{\mathrm{T}}$ $(95 \cdot 3 \%)$, Subtercola pratensis DSM $14246^{\mathrm{T}}(96 \cdot 6 \%)$ and Agreia bicolorata VKM Ac- $1804^{\mathrm{T}}(96 \cdot 4 \%)$ than to $L$. komagatae NBRC $15245^{\mathrm{T}}(94 \cdot 8 \%)$. L. komagatae NBRC $15245^{\mathrm{T}}$ was also close to Okibacterium fritillariae VKM Ac- $2059^{\mathrm{T}}$ and Plantibacter flavus DSM $14012^{\mathrm{T}}(94 \cdot 8 \%$ similarity with both species). In any of the trees, the tested strains were clearly shown to form an independent clade on their own.

It was notable from the phylogenetic tree that the three members of the genus Subtercola failed to form a single phylogenetic clade (Fig. 1). A. bicolorata VKM Ac- $1804^{\mathrm{T}}$ was consistently recovered as a clade with $S$. pratensis DSM $14246^{\mathrm{T}}\left(99 \cdot 7 \%\right.$ similarity) and S. boreus DSM $13056^{\mathrm{T}}$ $(97 \cdot 0 \%)$ in the phylogenetic trees. The taxonomic position of Subtercola frigoramans was in doubt, as it formed an independent lineage in Fitch-Margoliash and maximumlikelihood trees (data not shown). Further studies may be needed to resolve the ambiguity between the genera Agreia and Subtercola.

Separation of the tested strains from related genera, such as 


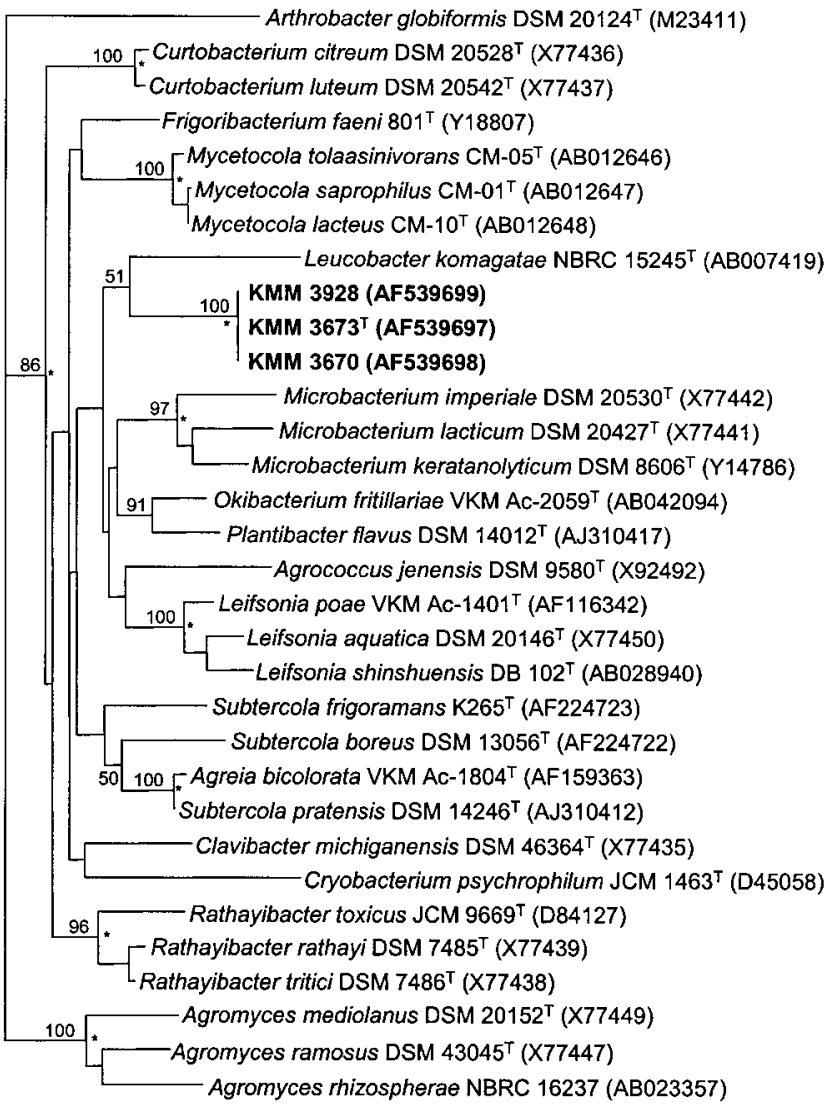

$\underline{0.01}$

Fig. 1. Phylogenetic tree showing the relationship between the novel KMM strains and other representative members of the family Microbacteriaceae. Asterisks indicate generic branches that were also recovered by using the Fitch-Margoliash and maximum-likelihood algorithms. Numbers at generic nodes and above indicate levels of bootstrap support (\%) from 1000 resampled datasets. Bar, 0.01 substitutions per nucleotide position.

Agreia, Leifsonia, Leucobacter and Subtercola, is also supported clearly by comparison of their chemotaxonomic and phenotypic characteristics (Table 1). Members of these related genera contain a major amount of DAB in their cell walls, which is not present in those of the tested strains. The tested strains lack motility, which separates them from Agreia and Leifsonia.

There are only a few records of isolation of members of the family Microbacteriaceae from the aquatic environment, e.g. Microbacterium barkeri and Microbacterium laevaniformans from activated sludge (Dias \& Bhat, 1962; Dias et al., 1962) and S. boreus and S. frigoramans from groundwater (Männistö et al., 2000). However, all reported isolations were from freshwater samples and there has been no report of isolation from marine samples.

It is still to be confirmed whether the tested strains are indeed indigenous to the particular environment where the
Table 2. Differential phenotypic properties of the strains tested Strains: 1, KMM 3673 ; 2, KMM 3670; 3, KMM 3928.

\begin{tabular}{|lccc|}
\hline Characteristic & $\mathbf{1}$ & $\mathbf{2}$ & $\mathbf{3}$ \\
\hline Hydrolysis of Tween 80 & - & - & + \\
Acid from: & & & \\
$\quad$ Arabinose & $-^{*}$ & + & $-{ }^{*}$ \\
L-Fucose & $-*$ & + & + \\
Mannitol & - & + & + \\
Susceptibility to ( $\mu$ g per disc): & & & \\
Benzylpenicillin (10) & - & + & - \\
Lincomycin (15) & + & + & - \\
Oleandomycin (15) & + & + & - \\
\hline
\end{tabular}

${ }^{*}$ Alkaline reaction.

samples were taken from. However, considering that multiple strains were isolated, all strains grew well in the presence of salt and a few other Gram-positive strains that displayed phenotypic characteristics similar to these strains were also isolated (data not shown), their isolation is not likely to be incidental. From the above evidence, strains KMM 3670, KMM 3673 ${ }^{\mathrm{T}}$ and KMM 3928 obviously form a distinct centre of taxonomic variation at the generic level in the family Microbacteriaceae; accordingly, a novel genus is proposed to accommodate this group of bacteria from the marine environment, namely Salinibacterium gen. nov.

Although strains KMM 3670, KMM $3673^{\mathrm{T}}$ and KMM 3928 shared an identical $16 \mathrm{~S}$ rDNA sequence, they could be distinguished from one another by comparison of phenotypic characteristics (Table 2). The strains shared most biochemical properties, such as enzyme activities and degradation of organic compounds, but were different in acid-forming ability from selected carbohydrates. There were no apparent differences in morphological features, as the three strains shared key morphological properties (such as cell shape and staining properties), lacked motility and spore formation and also formed colonies that were phenotypically indistinguishable on agar plates. The above evidence is considered to be sufficient to assign the three strains to a single species, for which the name Salinibacterium amurskyense sp. nov. is proposed.

\section{Description of Salinibacterium gen. nov.}

Salinibacterium (Sa.li.ni.bac.te' ri.um. L. n. salinum saltcellar; Gr. dim. n. bakterion a small rod; N.L. neut. n. Salinibacterium a saline bacterium).

Gram-positive, high-G+C, non-motile, aerobic, nonspore-forming, irregular rods. Mycolic acid is absent. Metabolism is respiratory, but acids can also be formed from some sugars. Arginine dihydrolase-, oxidase- and urease-negative, but catalase-positive. Nitrate is not reduced and hydrogen sulfide is not produced. Grows in the presence of $\mathrm{NaCl}$. Grows at mesophilic temperatures and around 
neutral $\mathrm{pH}$. Cell-wall peptidoglycan is type B; lysine and ornithine are the major diamino acids. Muramic acid contains acetyl residues. Principal phospholipids are phosphatidylglycerol and diphosphatidylglycerol. Cellular fatty acids consist of branched, saturated species; major components are 12-methyl tetradecanoic acid (anteiso$\mathrm{C}_{15: 0}$ ) and 14-methyl pentadecanoic acid (iso- $\mathrm{C}_{16: 0}$ ). Predominant menaquinone is MK-11; a smaller amount of MK-10 is also present.

The type and only species to date is Salinibacterium amurskyense. Member of the family Microbacteriaceae; characteristics that differentiate Salinibacterium gen. nov. from the other genera of the family are given in Table 1.

\section{Description of Salinibacterium amurskyense sp. nov.}

Salinibacterium amurskyense (a.mur.sky.en'se. N.L. neut. adj. amurskyense referring to Amursky Bay, the geographical location where the organism was first isolated).

General morphological and chemotaxonomic properties are as given in the generic description. Grows between 4 and $37^{\circ} \mathrm{C}$ (with optimal growth at $25-28{ }^{\circ} \mathrm{C}$ ), between $\mathrm{pH} 4 \cdot 5$ and $11 \cdot 0$ (with optimal growth at around $\mathrm{pH} 7 \cdot 2-7 \cdot 5$ ) and in the presence of $0-10 \% \mathrm{NaCl}$ (with optimal growth at $1-3 \%)$. Gelatin and DNA are degraded, but agar, casein, starch, cellulose, alginate, chitin and Tweens 20 and 40 are not. Acid is produced from rhamnose and glycerol. Acid is not produced from acetate, $\mathrm{N}$-acetylglucosamine, adonitol, cellobiose, dulcitol, fumarate, galactose, glucose, inositol, lactose, malate, maltose, melibiose, raffinose, sorbitol, sorbose, sucrose or xylose. Susceptible to ampicillin $(10 \mu \mathrm{g}$ per disc), carbenicillin $(100 \mu \mathrm{g})$ and streptomycin $(10 \mu \mathrm{g})$, but resistant to gentamicin $(10 \mu \mathrm{g})$, kanamycin $(30 \mu \mathrm{g})$, neomycin $(30 \mu \mathrm{g})$, polymyxin $\mathrm{B}(300 \mathrm{U})$ and tetracycline $(30 \mu \mathrm{g})$. DNA G $+\mathrm{C}$ content of the type strain is $61 \cdot 0 \mathrm{~mol} \%$.

The type strain is KMM $3673^{\mathrm{T}}\left(=\mathrm{KCTC} 9931^{\mathrm{T}}\right)$. Isolated from sea-water samples taken from Amursky Bay of the Gulf the Peter the Great, East Sea.

\section{Acknowledgements}

This work was supported by grant no. KBM1000212 from the Korea Research Council of Fundamental Science \& Technology, Republic of Korea, grant 02-04-49517 from the Russian Foundation for Basic Research and grant 03-19 from the Ministry for Industry, Science and Technologies of the Russian Federation.

\section{References}

Behrendt, U., Ulrich, A., Schumann, P., Naumann, D. \& Suzuki, K. (2002). Diversity of grass-associated Microbacteriaceae isolated from the phyllosphere and litter layer after mulching the sward; polyphasic characterization of Subtercola pratensis sp. nov., Curtobacterium herbarum sp. nov. and Plantibacter flavus gen. nov., sp. nov. Int J Syst Evol Microbiol 52, 1441-1454.
Bousfield, I. J., Keddie, R. M., Dando, T. R. \& Shaw, S. (1985). Simple rapid methods of cell wall analysis as an aid in the identification of aerobic coryneform bacteria. In Chemical Methods in Bacterial Systematics, pp. 221-236. Edited by M. Goodfellow \& D. E. Minnikin. London: Academic Press.

Chun, J. (2001). PHYDIT version 3.1 (http://plaza.snu.ac.kr/ jchun/ phydit/).

Collins, M. D. \& Bradbury, J. F. (1992). The genera Agromyces, Aureobacterium, Clavibacter, Curtobacterium, and Microbacterium. In The Prokaryotes, pp. 1354-1368. Edited by A. Balows, H. G. Trüper, M. Dworkin, H. Harder \& K.-H. Schleifer. Berlin: Springer.

Davis, M. J., Gillaspie, A. G., Jr, Vidaver, A. K. \& Harris, R. W. (1984). Clavibacter: a new genus containing some phytopathogenic coryneform bacteria, including Clavibacter xyli subsp. xyli sp. nov., subsp. nov. and Clavibacter xyli subsp. cynodontis subsp. nov., pathogens that cause ratoon stunting disease of sugarcane and bermudagrass stunting disease. Int $J$ Syst Bacteriol 34, 107-117.

Dias, F. F. \& Bhat, J. V. (1962). A new levan producing bacterium, Corynebacterium laevaniformans nov. spec. Antonie van Leeuwenhoek J Microbiol Serol 28, 63-72.

Dias, F. F., Bilimoria, M. H. \& Bhat, J. V. (1962). Corynebacterium barkeri, nov. spec., a pectinolytic bacterium exhibiting a biotin-folic acid interrelationship. J Indian Inst Sci 44, 59-67.

Evtushenko, L. I., Dorofeeva, L. V., Subbotin, S. A., Cole, J. R. \& Tiedje, J. M. (2000). Leifsonia poae gen. nov., sp. nov., isolated from nematode galls on Poa annua, and reclassification of 'Corynebacterium aquaticum' Leifson 1962 as Leifsonia aquatica (ex Leifson 1962) gen. nov., nom. rev., comb. nov. and Clavibacter xyli (Davis et al. 1984) gen. nov., comb. nov. Int J Syst Evol Microbiol 50, 371-380.

Evtushenko, L. I., Dorofeeva, L. V., Dobrovolskaya, T. G., Streshinskaya, G. M., Subbotin, S. A. \& Tiedje, J. M. (2001). Agreia bicolorata gen. nov., sp. nov., to accommodate actinobacteria isolated from narrow reed grass infected by the nematode Heteroanguina graminophila. Int J Syst Evol Microbiol 51, 2073-2079.

Evtushenko, L. I., Dorofeeva, L. V., Krausova, V. I., Gavrish, E. Yu., Yashina, S. G. \& Takeuchi, M. (2002). Okibacterium fritillariae gen. nov., sp. nov., a novel genus of the family Microbacteriaceae. Int J Syst Evol Microbiol 52, 987-993.

Felsenstein, J. (1981). Evolutionary trees from DNA sequences: a maximum likelihood approach. J Mol Evol 17, 368-376.

Felsenstein, J. (1993). PHYLIP (phylogeny inference package), version 3.5c. Department of Genetics, University of Washington, Seattle, USA.

Fitch, W. M. \& Margoliash, E. (1967). Construction of phylogenetic trees. Science 155, 279-284.

Groth, I., Schumann, P., Weiss, N., Martin, K. \& Rainey, F. A. (1996). Agrococcus jenensis gen. nov., sp. nov., a new genus of actinomycetes with diaminobutyric acid in the cell wall. Int J Syst Bacteriol 46, 234-239.

Hugh, R. \& Leifson, E. (1953). The taxonomic significance of fermentative versus oxidative metabolism of carbohydrates by various gram-negative bacteria. J Bacteriol 66, 24-26.

Jones, D. \& Collins, M. D. (1989). Irregular, nonsporing Grampositive rods. In Bergey's Manual of Systematic Bacteriology, vol. 2, pp. 1261-1266. Edited by P. H. A. Sneath, N. S. Mair, M. E. Sharpe \& J. G. Holt. Baltimore: Williams \& Wilkins.

Jukes, T. H. \& Cantor, C. R. (1969). Evolution of protein molecules. In Mammalian Protein Metabolism, pp. 21-132. Edited by H. N. Munro. New York: Academic Press. 
Kämpfer, P., Rainey, F. A., Andersson, M. A., Nurmiaho Lassila, E.-L., Ulrych, U., Busse, H.-J., Weiss, N., Mikkola, R. \& SalkinojaSalonen, M. (2000). Frigoribacterium faeni gen. nov., sp. nov., a novel psychrophilic genus of the family Microbacteriaceae. Int J Syst Evol Microbiol 50, 355-363.

Kim, S. B., Falconer, C., Williams, E. \& Goodfellow, M. (1998). Streptomyces thermocarboxydovorans sp. nov. and Streptomyces thermocarboxydus sp. nov., two moderately thermophilic carboxydotrophic species from soil. Int J Syst Bacteriol 48, 59-68.

Leifson, E. (1963). Determination of carbohydrate metabolism of marine bacteria. J Bacteriol 85, 1183-1184.

Lelliott, R. A., Billing, E. \& Hayward, A. C. (1966). A determinative scheme for the fluorescent plant pathogenic pseudomonads. J Appl Bacteriol 29, 470-489.

Männistö, M. K., Schumann, P., Rainey, F. A., Kämpfer, P., Tsitko, I., Tiirola, M. A. \& Salkinoja-Salonen, M. S. (2000). Subtercola boreus gen. nov., sp. nov. and Subtercola frigoramans sp. nov., two new psychrophilic actinobacteria isolated from boreal groundwater. Int J Syst Evol Microbiol 50, 1731-1739.

Marmur, J. \& Doty, P. (1962). Determination of the base composition of deoxyribonucleic acid from its thermal denaturation temperature. J Mol Biol 5, 109-118.

Minnikin, D. E., O’Donnell, A. G., Goodfellow, M., Alderson, G., Athalye, M., Schaal, A. \& Parlett, J. H. (1984). An integrated procedure for the extraction of bacterial isoprenoid quinones and polar lipids. J Microbiol Methods 2, 233-241.

Park, Y.-H., Suzuki, K., Yim, D. G. \& 7 other authors (1993). Suprageneric classification of peptidoglycan group B actinomycetes by nucleotide sequencing of $5 \mathrm{~S}$ ribosomal RNA. Antonie van Leeuwenhoek 64, 307-313.

Saitou, N. \& Nei, M. (1987). The neighbor-joining method: a new method for reconstructing phylogenetic trees. Mol Biol Evol 4, 406-425.

Schleifer, K. H. \& Kandler, O. (1972). Peptidoglycan types of bacterial cell walls and their taxonomic implications. Bacteriol Rev 36, 407-477.

Smibert, R. M. \& Krieg, N. R. (1994). Phenotypic characterization. In Methods for General and Molecular Bacteriology, pp. 607-655. Edited by P. Gerhardt, R. G. E. Murray, W. A. Wood \& N. R. Krieg. Washington, DC: American Society for Microbiology.

Stackebrandt, E., Rainey, F. A. \& Ward-Rainey, N. L. (1997). Proposal for a new hierarchic classification system, Actinobacteria classis nov. Int J Syst Bacteriol 47, 479-491.
Suzuki, K., Sasaki, J., Uramoto, M., Nakase, T. \& Komagata, K. (1997). Cryobacterium psychrophilum gen. nov., sp. nov., nom. rev., comb. nov., an obligately psychrophilic actinomycete to accommodate "Curtobacterium psychrophilum" Inoue and Komagata 1976. Int J Syst Bacteriol 47, 474-478.

Takeuchi, M. \& Hatano, K. (1998). Union of the genera Microbacterium Orla-Jensen and Aureobacterium Collins et al. in a redefined genus Microbacterium. Int J Syst Bacteriol 48, 739-747.

Takeuchi, M., Weiss, N., Schumann, P. \& Yokota, A. (1996). Leucobacter komagatae gen. nov., sp. nov., a new aerobic grampositive, nonsporulating rod with 2,4-diaminobutyric acid in the cell wall. Int J Syst Bacteriol 46, 967-971.

Tarrand, J. J. \& Gröschel, D. H. M. (1982). Rapid, modified oxidase test for oxidase-variable bacterial isolates. J Clin Microbiol 16, $772-774$

Thornley, M. (1960). The differentiation of Pseudomonas from other Gram-negative bacteria on the basis of arginine metabolism. J Appl Bacteriol 23, 37-52.

Tsukamoto, T., Takeuchi, M., Shida, O., Murata, H. \& Shirata, A. (2001). Proposal of Mycetocola gen. nov. in the family Microbacteriaceae and three new species, Mycetocola saprophilus sp. nov., Mycetocola tolaasinivorans sp. nov. and Mycetocola lacteus sp. nov., isolated from cultivated mushroom, Pleurotus ostreatus. Int J Syst Evol Microbiol 51, 937-944.

Uchida, K. \& Seino, A. (1997). Intra- and intergeneric relationships of various actinomycete strains based on the acyl types of the muramyl residue in cell wall peptidoglycans examined in a glycolate test. Int J Syst Bacteriol 47, 182-190.

Yamada, K. \& Komagata, K. (1972). Taxonomic studies on coryneform bacteria. IV. Morphological, cultural, biochemical, and physiological characteristics. J Gen Appl Microbiol 18, 399-416.

Zgurskaya, H. I., Evtushenko, L. I., Akimov, V. N., Voyevoda, H. V., Dobrovolskaya, T. G., Lysak, L. V. \& Kalakoutskii, L. V. (1992). Emended description of the genus Agromyces and description of Agromyces cerinus subsp. cerinus sp. nov., subsp. nov., Agromyces cerinus subsp. nitratus sp. nov., subsp. nov., Agromyces fucosus subsp. fucosus sp. nov., subsp. nov., and Agromyces fucosus subsp. hippuratus sp. nov., subsp. nov. Int J Syst Bacteriol 42, 635-641.

Zgurskaya, H. I., Evtushenko, L. I., Akimov, V. N. \& Kalakoutskii, L. V. (1993). Rathayibacter gen. nov., including the species Rathayibacter rathayi comb. nov., Rathayibacter tritici comb. nov., Rathayibacter iranicus comb. nov., and six strains from annual grasses. Int J Syst Bacteriol 43, 143-149. 